\title{
Causing a Ruckus: Complicity and Performance in Stories of Port Moody
}

\author{
MATTHEW HAYES
}

$\mathrm{T}$

This article is about the suicide of a small-town chief of police, which - according to some - did not actually happen. It is certain that Albert William Kruger, of Port Moody, British Columbia, died on 24 May 1960 after serving as chief of police since 1946. But I encountered three versions of the story of his death. First, that it was not suicide at all, but rather a heart attack that claimed his life while he was at home. Second, that it was indeed suicide, and he shot himself in the head in his home. Third, and most sensational of all, that he attempted to commit suicide by gunshot in his car, but that he failed and dragged himself to his home where he shortly thereafter died, having left a trail of blood behind him. 
The disagreement over this story became central to what was otherwise a conventional public history job. During the summer of 2011, I was employed by the Port Moody Station Museum to research and help write a history book on the City of Port Moody's first 100 years. At the time, I was an MA student in anthropology at Simon Fraser University, hired for my research, interview and writing skills but also because the funding for the position came from a federal government grant intended to hire students. The job required me to comb through the museum's archives - a collection of several hundred artefacts, nearly ten thousand photographs, dozens of hours of recorded oral histories dating back to the 1970s, and hundreds of pages of written material - in order to build up a history of the city's early days according to a collection of themes. The chapters eventually published in the book Tracks in Time give a survey of life and work in the small city, including the importance of the Canadian Pacific Railway, local mills and refineries, and the City's struggle to differentiate itself from the emerging metropolis of Vancouver. The book also provides a look at some of Port Moody's memorable characters and events, an aspect on which I focused my energies. In the end, I served as the lead researcher, contributing text to seven of the book's eleven chapters.

The job was one firmly rooted in a philosophy of public history. The museum was run on a day-to-day basis by the full-time general manager and curator and took on special projects during the summer by hiring several students. However, the Port Moody Heritage Society, a board of volunteers, oversaw the museum's operation, and it is this organization that published Tracks in Time. The board members were long-time community members, several of which contributed text to the book. One of the main goals of the project was to involve the community in the research and development phase in an integral way, reflecting Michael Frisch's seminal notion of 'shared authority'. . Despite hiring me as an 'expert', it was always intended that one of the main sources of information would be those community members who had lived through some of the times and events I was to research.

This collected wealth of first-hand experience was a resource to use. But the expectation to also take into account the desires of those providing the stories led to some simmering tension. I was told on more than one occasion to 'put the good stories in'. What became clear is that this actually meant leave out the bad ones. The story of the chief of police who may or may not have committed suicide was clearly one of the bad ones. 
This story of potential suicide - although there were other sensational and outlandish stories like it - marked a turning point in the project. It opened up a way into an analysis of this experience as one shaped by an expectation to conduct a rigorous history, in tension with the community's desire to portray a rosy picture of the city. Historians have described this tension as the difference between doing 'history' and 'heritage'. 'History explores and explains pasts grown ever more opaque over time', David Lowenthal writes, whereas 'heritage clarifies pasts so as to infuse them with present purposes. ${ }^{\prime}$ Ludmilla Jordanova articulates this distinction in terms of the 'historian's imagination', central to which is the capacity to 'understand conditions that are not part of their own immediate experience' and in so doing resist the appropriation of history by 'special interests'. She writes that this position exists in tension with the aspect of public history that is innately interested, which tends to become aligned with these so-called special interests.

Steven High describes this as the difference between 'memory recovery' and interrogating stories for their meaning. Indeed, the very idea of the 'community' the museum mobilized for this project is contested and deeply affected how stories were told and received. This article uses the concepts of complicity and performance - theory derived from the discipline of Anthropology - to reflect on doing public and oral history in small towns. It explores the controversy around Chief Kruger's suicide as a way into a discussion on ethics, expectations, and shared authority.

\section{CAUSING A RUCKUS}

In its very early days Port Moody was on the verge of good things. In 1879, the small town was named the western terminus of the Canadian Pacific Railway and business immediately boomed. Businesses and workers - many of them Chinese immigrants - flooded into town and a prosperous frontier community began to develop. The success was short-lived. Just five years later Vancouver was named the new terminus. Despite a number of court cases and blockades by landowners who attempted to stop further construction of the railway, Vancouver became the end of the line on 23 May 1887. Port Moody immediately entered a depression with people leaving almost as quickly as they arrived. The decision to relocate the terminus profoundly affected the town, and still frames its history even today.

The history of Port Moody is one of being jilted. The citizens became victims of events and decisions outside their control, and this narrative has structured subsequent historical renderings. ${ }^{\urcorner}$People have of course 
moved on. But the bitterness about this decision over one hundred years ago is still apparent. Tracks in Time begins with this moment and everything that comes after is implicitly framed as a result. This might help account for why there was so much insistence on 'putting the good stories in'. The old-timers I spoke to clearly wished for a book that portrayed their city in a golden light. Except for the founding story of victimhood controversy was to be avoided. All else was just having fun, causing a ruckus. I encountered a frontier mentality ${ }^{8}$ while doing the research, especially in the recorded oral histories and during a number of focus groups.

To help achieve the goal of community participation, monthly 'reminiscing meetings' were held at the local municipal hall. With refreshments provided, I met with a group of ten to twenty 'old-timers' as they liked to be called - to talk about the old days and glean stories and information from them. The audio from these sessions was recorded, which I used for my research. The recordings were never transcribed and to my knowledge no one ever reviewed them. They did become part of the museum's oral history collection but seemed to sit slightly apart from the main body of oral histories, being qualitatively different from the previous interviews. No release forms were ever signed for them, likely because the museum and those who attended did not think of them as formal oral history interviews meant to pass on original knowledge. They thought of them more as mere aids to research already underway that simply needed some assistance with 'memory recovery', or as group tellings of the story that were meant more for entertainment and building social ties.

However, the intention was to use these meetings not only as a supplement to my research in the museum's archives. Frisch has described the use of oral history in this way as 'salsa', merely added flavour.' I was to collect quotes and fill in gaps left by the historical record. But I was also to use the meetings as a means of determining what the 'community' thought was most important to include in the book. There was no shortage of stories. The task was to whittle them down to a manageable and publishable amount, in a way that would capture the essence of the town. Many of these old-timers had lived in Port Moody their entire lives. As an outsider - I came from Ontario - I expected a certain amount of ribbing. But even those who had lived in Port Moody for decades received the same treatment. At one meeting, a woman complained to me: 'I've lived here for nearly sixty years, and I'm still one of the newcomers!' 
The issue of insider/outsider status is ever-present when doing community research. Jeremy Brecher described how, even after several years, he was not accepted as an insider by a group of former brass workers with whom he was doing his research. At the very best, he achieved the status of 'pet outsider' ${ }^{10}$ My own position in Port Moody was similar. I never expected to be accepted as an insider, considering my tenure there would only last several months. But I was accepted as an expert because of the museum's endorsement. With the blessing of this gatekeeper, I was given access to the community. They granted me a certain level of trust, knowing that whatever I did would be guided and checked by the museum's staff, who by virtue of working in the community full-time, possessed more social capital." But this trust only extended so far. And this became clear during one of the reminiscing meetings.

I may not have come across the story of Chief Kruger at all if it had not been for a slip of the tongue. While asking about the police force during the post-war period Kruger eventually came up. Then, in the kind of hushed voice that immediately invokes the feeling of being 'off the record',,$^{2}$ they said: 'and you all know what happened to him.' Sitting in the meeting, I saw the other old-timers nod. Clearly the story was a public secret. But I had not yet heard it. I asked what had happened and was given a very rushed version before the topic was abruptly changed. Afterward, I asked the other employees of the museum about the story, and was told the part about the suicide was likely untrue. The sensational story was shrugged off as something the old-timers had probably exaggerated over time. It was clear that the story was taboo, and also not a priority for the book. ${ }^{13}$ Over the rest of the summer I heard the other versions of the story from different people. Some scoffed at the more graphic versions, also denouncing them as exaggeration. Others would nod solemnly, agreeing that there was truth to the suicide tale.

\section{COMMUNITY IN TRANSITION}

For the purposes of this article, it does not necessarily matter what actually happened, although I did eventually find out. What I want to highlight instead is how the composition of the community members, and their nostalgic recollections, shaped the final product.

Port Moody, in its early days, was a frontier town. Many of the people and events I was told about reflect this in the way that the stories, decades and generations removed, were filtered to serve specific purposes. The old-timers with whom I worked often referred to the 'good ol' days', but it was at first unclear to which days, specifically, they 
were referring. No one who had seen the founding years of Port Moody was still alive. The old-timers in the reminiscing meetings spoke about their own childhoods and adult lives, which generally covered the 1930s through to the 1960s. It became obvious that the old-timers had specific recollections from this latter period, having lived through it, and so did refer to it as the good old days. But they also regularly referred to the late nineteenth-century years in the same way, clearly the result of hearing stories about them from their parents and grandparents. The same rosy tint covered practically every period up until the very recent past, beginning perhaps when the old-timers started retiring and seeing a new population move into town and take up work.

Port Moody in the twenth-first century was rapidly changing. It was expanding with a surge of newcomers migrating outward from Vancouver. A common concern among the old-timers was that the town would simply become a dormitory community for those who worked in Vancouver. The old mills and factories that employed the men who attended the reminiscing meetings had long since closed and new employment was difficult to obtain. What new jobs that were available tended to be in the emerging creative sector, something with which the old-timers found it difficult to connect. I was more than once exposed to a lowly opinion of cell phones and kids-these-days who were born with the knowledge of how to swipe screens with their fingers.

What the community members feared was, in fact, a loss of community. This is not by any means a unique situation. ${ }^{14}$ But it permeated the discussions at the reminiscing meetings, focused as they were on the past, on the good old days. Further complicating the situation for them was the recent influx of new immigrants to the city. Without exception, the community members with whom I was tasked to work were white and middle-class. That is, the community that was to help determine the priorities for the book was homogenous in race and age. Racism was never explicit during these meetings. But certain wellworn stories attested to historical racial tension in the town. When Port Moody was named the western terminus of the Canadian Pacific Railway, a number of Chinese men were hired to work the track. ${ }^{15}$ They were said to have lived together in a shack, their wives and children left behind in China. It was always made clear that the shack was located on the outskirts of the town and none of them ever moved into better accommodations in town. Among the stories were also featured the ever-present Chinese laundry - offering the cheapest rates - and a Chinese fish vendor, pushing his cart through the streets. ${ }^{16}$ 
The common thread in stories of racial minorities was amazement at their clever entrepreneurship or their unflagging stamina and hardiness. One story tells of a train accident in 1913 that claimed the lives of five Sikh men who all became pinned between two cars that crashed into one another. According to long-time resident, Allan Ottley, another Sikh man had his nose struck off in the accident. But promptly 'picked it up and carried it with him to the hospital, where it was sewed back onto his face. ${ }^{\prime 1}$ These kinds of stories made for entertainment, but of a certain kind. They were the safe stories to tell. The poor living conditions of immigrant men were known, but never discussed as a result of discrimination. It was simply how it was. And it was clear that racial minorities and the white population in Port Moody rarely mixed..$^{18}$

The stories I heard of the general population emphasised the frontier mentality of simply having a good time, despite the bad luck and the resistance of the natural landscape the town had encountered. ${ }^{19}$ Boys would be boys, especially when it came to drinking in bars and the occasional fisticuffs. Meco Alvero, the proprietor of the popular Tourist Hotel, was recorded in one oral history recounting the story of a man who, after being ejected from the bar for excessive inebriation, later came back with a chainsaw. After the bartender refused to serve him, the man fired up the chainsaw and began cutting down one of the building's support beams. Other stories told of local boys and men committing petty crimes, of robberies and assaults - 'ding-dong fights'. ${ }^{20}$ But these stories were nostalgic. They were told amidst laughter, clearly intended to convey the sense that these incidents were not serious, and in fact hearkened back to a time of more conservative values and morals that made the town safe for these kinds of antics. They were values that the old-timers felt were slowly eroding. Port Moody had become, in the words of Leon Fink, a 'lost cause', 'dedicated to the disappeared millworking family.' ${ }^{21}$

This romanticisation belied the fact that much of the work the men did was incredibly dangerous and in many cases resulted in injury or death..$^{2}$ It also served to hide racial tensions and excuse the fact that men spent significant time at local watering holes, leaving their wives at home to raise the children. The myth-making I encountered revealed a desire to strategically frame Port Moody's history by omitting embarrassing details and focusing instead on 'the good stories'. In the case of minorities, this inevitably meant leaving out all mention of them, glossing over their stories as curiosities or including them as a way of displaying the benevolence of the white population..$^{23}$ As Cauvin writes in his discussion of historic sites, ' $[\mathrm{f}]$ or a long time, historic preservation 
focused on the "legacy of wealth and power". In doing so, it contributed to silencing the memories of minorities. ${ }^{24}$

In the case of Port Moody, the legacy of wealth and power inevitably meant focusing on stories of the white middle-class, such as those who attended the reminiscing meetings. Sommer notes that with the rise of social history in the 1970s, 'stories of the past began to become more nuanced. Those that had been suppressed, such as those uncovered by new social history studies of class, race, gender, and family, began to surface. ${ }^{\prime 2}$ However, this change was not overly obvious while sitting in the reminiscing meetings. Mention was made of minorities but only ever in the superficial way described above. Jordanova writes that it is the historian's ethical obligation to understand that the past 'is constantly being used and re-presented, and ideally should not be appropriated by special interests. ${ }^{26}$ Attempting to strike this balance was especially challenging considering one of the stated goals of the Port Moody history book was to provide newcomers - the majority of which were second- or third- generation immigrants - with a means of accessing Port Moody's past. It also created an uncomfortable situation for me, tasked as I was with researching and writing an accurate history.

\section{AUtHORITY, COMPLICITY, PERFORMANCE}

Historians have described a distinction between doing history and heritage. 'While the latter upholds a standard of distanced reflection and continual reinterpretation,' Leon Fink has noted, 'the former aims for fixity and wholeness, evoking emotions of pride and sometimes even reverence. ${ }^{2 z}$ This nicely captures the problem I encountered in Port Moody: the museum had hired me to write history, under the constraints of a heritage project. In Lowenthal's words, heritage was 'misconceived' as history. ${ }^{28}$ This led to certain ethical questions. What if the museum or community members requested I change what I write? Should I continue to research stories like the police chief's suicide if it was made clear they were not wanted for the book? How would I negotiate the inclusion of potentially embarrassing stories - like the treatment of minorities - to ensure a more comprehensive account was achieved? ${ }^{29}$

Rebecca Conard clearly tackles this issue when she writes:

$[\mathrm{H}]$ istorians who enjoy a constitutional right of free speech, supported by an academic tradition that encourages the open expression of ideas, have license to protest when this freedom is threatened. Public historians, in contrast, are likely to find that their freedom of expression is constrained in one way or another, and as public historians nudge the process of social change by insisting on 
interpreting controversial events and contested history with scholarly integrity, the more clearly these constraints are revealed.so

The story of Chief Kruger's suicide revealed these constraints because it was so sensational. It struck an entirely different chord than the rest of the stories, and for the museum went too far in insisting on interpreting controversial events. What is interesting is that I rarely felt these constraints otherwise. I was only present at the museum for a short time. But because of the vast amount of material I went through I quickly became an expert in the eyes of the old-timers. While at first I listened attentively and took notes when the old-timers told me stories, I was eventually able to participate in the telling. In many cases I even provide details they either did not know or had forgotten. In several instances, I was approached by community members looking for information about people they had personally known who I had only encountered through the archival record.

I became an authority on the history of Port Moody. This is somewhat ironic, considering I remained an outsider and there was still a level of distrust, evident every time I tried to bring up stories like the suicide. But I realised that for the rest of the city's history, I had a power over what was written. There existed a formal contract between myself and the museum, laying out the division of labour and responsibilities. I was responsible for doing the research and writing the first drafts. Final copy editing and arrangement was up to the museum. The museum reserved the right to fact-check everything I wrote, as well as bring in other contributing writers or local historians to look over my work. But they never did so. The facts I included in my writing were never questioned. In one instance I was researching one of Port Moody's various pubs, trying to determine when it closed. I had narrowed the year to either 1960 or 1961 and eventually decided on the former, based on the written material I had at hand. One of the old-timers openly disagreed with me, insisting the bar closed in 1961. In the end, the museum endorsed my choice. This is a relatively innocuous example. But it served to highlight how much trust I did indeed have, that the museum would take my word over a long-time resident who was there when the bar actually closed.

Also contributing to this decision, and others like it, was the gender of the community members who attended the reminiscing meetings. The group was certainly homogenous in terms of race, class and age. All were white and in their senior years. Despite many stories of hardship during the 1930s, they were also all comfortably middle class. And they were mostly men. Several women did attend the meetings and they did 
speak up and provide stories of the town and its people. But that was usually the only thing they provided: stories. The facts - dates, locations, names - were provided by the men in attendance. Without it ever being stated explicitly, it became clear that when a specific fact was in doubt, we were all to turn to the men. They were the repositories of a more official account of things. By the end of the project, this authority was also extended to me. In the case of the above example, of the year the pub closed, it was one of the women at the meetings who disputed my claim. I suspect this combination of factors determined the museum's decision to take my account as official..$^{31}$

Results from 'The Canadians and Their Pasts' project - a mass survey project that aimed 'to probe people's historical consciousness' indicate that 'museums were rated as the single most trustworthy source' of historical information. This was due to 'the presence of artefacts and primary documents, the belief that museums were neutral and run by professionals, and the confidence resulting from using multiple sources of information.' ${ }^{\prime 2}$ Second only to museums in trustworthiness, the survey respondents said, were fact-based historical books. This certainly helps account for why my conclusions were trusted, despite being a newcomer. Yet, there was one distinction that does not entirely agree with the results of this project.

Instead of valuing the supposed neutrality of museums, the community members with whom I engaged came to trust me because they thought, in effect, I was on their side. I do not mean sides in the sense of a pitched battle between opposing forces. Rather, on their side in the sense of working with them toward a clear goal: that of painting a mythical portrait of Port Moody. In one sense, I was considered an advocate. My job was to collect all the stories and ensure that they were shepherded carefully and translated appropriately so that the goals were achieved.

The anthropologist George Marcus describes this relationship as one of complicity. He intends this term not in its usual meaning of 'partnership in an evil action', but rather that of the 'state of being complex or involved. ${ }^{\prime 3}$ Ethnographers are required to construct their field of study from an assemblage of sites, and any one of these sites whether a physical location or an intangible network of friends and acquaintances - may demand an allegiance or 'circumstantial activism.' ${ }^{34}$ These various allegiances are enacted 'to greater or lesser extents' at each site, ${ }^{35}$ and they serve to turn the ethnographer into a de facto activist. The term is meant here as dedication to a person or group in the field. 
The community members in Port Moody articulated my role in the project as an activist in this sense, working toward their goals, which had been imparted to me through the process of actively listening to their stories. ${ }^{36}$ I believe this was the case based on what happened after it became clear I was not entirely dedicated to this task. In the act of repeatedly asking about the police chief's suicide, despite the request to leave it alone, I betrayed the complicity. ${ }^{3 z} \mathrm{I}$ began to sense a much cooler response from some community members nearer the end of the project..$^{38}$ It was as if they felt I had betrayed the trust the museum had bestowed on me. If I had wished to sensationalise my own story, I imagine several of the regular community members would have harboured suspicions of me as some kind of spy.

This suspicion had as much to do with performance as complicity. When stories of Port Moody were told during the reminiscing meetings they were exciting. The old-timers clearly had a good time reliving the memories, and the fun of it was piecing together the stories, with multiple tellers each contributing a part. The liveliness of the sessions made for a stimulating introduction to the stories and what they lacked in concrete historical detail they made up for in spirit. But the telling was only good in the group. At several points in the research I telephoned or met in person with some old-timers and spoke to them individually. I asked them to repeat a story they had told in a meeting. On these occasions, the telling was sterile. Rather than the liveliness to which I had become accustomed, the telling was purely factual. In some cases, it became an interview rather than a telling; I had to prompt the old-timer with questions in order to even get the whole story out." On the phone, or one-on-one in person, the laughter and nostalgia of the stories disappeared. They became stilted. This speaks to the understanding the museum and the old-timers had between a formal oral history interview and the telling of a story. A formal interview was one-on-one, meant to convey information in as direct a manner as possible. A telling was a group collaboration that aimed more at solidifying community than passing on historical details.

According to Richard Bauman, every 'oral performance, like all human activity, is situated, its form, meaning, and functions rooted in culturally defined scenes or events'. He further writes that 'every performance will have a unique and emergent aspect, depending on the distinctive circumstances at play within it. ${ }^{\prime \prime 0}$ The stories were not a simple recitation of events and words, told the exact same way every time. They changed depending on the circumstances. Keith Sawyer writes that everyday conversations, such as the stories told in the reminiscing meetings, are actually fundamentally improvisational.". The 
people involved play off one another and so their words and these scripts can easily be changed. In this sense, oral history is also fundamentally collaborative..$^{22}$ It does not happen in isolation. It only happens during and through contact with others.

The difference between telling a story in a group and being interviewed for it also speaks to the division between oral history and ethnography. In a way, the vibrant tellings that occurred in the group speak more to ethnographic immersion. Micaela Di Leonardo outlined a number of key differences between oral history and ethnography. Most significantly, ethnographers define themselves through the practice of participant observation and immersion within the culture being studied. In so doing they focus more on analysing behaviour within group settings, whereas oral historians tend to focus on 'narrative and artefactual modes of data collection' confined to encounters between the smallest possible group - that is, between the interviewer and interviewee. ${ }^{43}$ The same information was given in the reminiscing meetings as during the telephone interviews. But the group setting brought out participant emotions in a way the one-on-one setting did not.

This is because, rather than the content of the stories themselves, the social bonds built during the telling of the stories was the main focus for the old-timers. They strove to tell the stories as accurately as they could, but I understood that they actually wanted to get together and interact. These sessions were about solidifying their friendships and their common histories. And in some cases, they were about rebuilding forgotten memories, using all the bits of various people's memories in order to piece together the puzzle of Port Moody's history. The sessions were thus not a matter of simply recollecting stories, but more a matter of making their history, in the moment, and remaking it every time they met.

As an outsider, I could only participate in this activity to a limited extent. Eventually, I was able to provide obscure factual details that could help spark a story, or help move it along if it became grounded. But I could never fully participate in the act of piecing it together as the old-timers could as a result of their lived experience. The best I could do was sit on the outside of the reminiscing meetings and try to soak in their energy while observing behaviour. This disconnect was further highlighted when I asked questions about stories like Chief Kruger's suicide, which was a memory the old-timers thought best forgotten. It did not fit into the lively performance of the meetings they attended, and so reminded them of my ambiguous - perhaps, suspicious - status. 
In reality, the situation was not this dramatic. By this time the project was winding down and the reminiscing meetings were occurring less frequently. But it was evident to me that the relationship had changed. The frameworks of complicity and performance are helpful here. But perhaps it is more effective to say that what actually occurred was a misunderstanding, one of expectations and goals." What some thought was a complicitous relationship was in reality one structured from the beginning by the differences between doing history and heritage.

\section{THE GOOD STORIES}

Anthropologist Karl Heider raised the problem of conflicting interpretations of events in his article 'The Rashomon Effect'. The classic 1950 film Rashomon, by the Japanese filmmaker Akira Kurosawa, is about an encounter in the woods between a bandit, and a samurai and his wife, which leads to the samurai's death. The film provides four different interpretations of how the death occurred, each of them presented visually and convincingly: 'unlike the familiar detective story on film, where accounts that are later impeached are given only verbally, Rashomon commits itself to, and convinces us of, the truth of each version in turn. And unlike the detective story, we are not given an explanation wrapped up nicely in truth at the end. ${ }^{\prime}$

The Rashomon Effect is certainly a tidy way of framing controversies such as Chief Kruger's suicide, as it highlights the fragmentary nature of storytelling. However, in the end I did in fact find out the truth about Chief Kruger. His death certificate states cause of death was 'termination of brain stem due to gun shot wound of head'. It was a suicide after all. What is more, the death certificate also notes the location of the death as 'highway' ${ }^{.6}$ So perhaps Kruger's attempt did indeed fail, and he dragged himself home. Or perhaps it succeeded and he was found in his car. I would have liked to include this story in Tracks in Time. As an outside researcher, I felt it spoke to the underlying tensions in the city's history. But it was not included. While I had control over my own contributions, the museum staff and advisory board made the final decisions on which ones to include. I wrote up a number of stories of people and events that did not make it into the book. The suicide was just one story among these and I never did write it up. When the museum staff made it clear that Kruger's story was not a priority, I was forced to leave it aside in favour of the others. It was not until I revisited my experience and began writing this article - years later - that I searched the provincial archives and found Kruger's death certificate. 
In any case, the story of a grisly suicide by a respected civil servant was unacceptable material for the kind of book Port Moody wished to see. Or, as I have argued in this article, the kind of book that the small group of community members with whom I worked wished to see.

The book was a means by which this group was able to meet and relive certain memories. It was a way of contributing to a legacy of their choosing, ensuring that only the good stories were put in. ${ }^{\sharp 7}$ The good stories were inevitably ones that reflected specific values, shaped by their experiences of race, class, gender and age. What the old-timers were looking for in this project was a confirmation of these values, which impacted upon, and at times conflicted with, my own experience of doing public and oral history. While in the end finding the concrete information about Chief Kruger was fascinating, the fact of it ceased to hold as much meaning for me. What meant more is how the controversy over this story cracked open the relationship I had with the community and the museum, allowing me to identify the disconnect between our expectations and goals, and to understand the stakes involved in this project for the old-timers.

\section{ENDNOTES}

' Jim Miller and Rebecca Clarke (eds), Tracks in Time, Port Moody Heritage Society, Port Moody, British Columbia, 2012.

${ }^{2}$ Michael Frisch, A Shared Authority: Essays on the Craft and Meaning of Oral and Public History, State University of New York, Albany, 1990.

${ }^{3}$ David Lowenthal, Possessed by the Past: The Heritage Crusade and the Spoils of History, Free Press, New York, 1996, pxi; see also Leon Fink, 'When Community Comes Home to Roost: The Southern Milltown as Lost Cause', in Journal of Social History, vol 40, no 1, 2006, pp119-45; Steven High, 'Sharing Authority in the Writing of Canadian History: The Case of Oral History', in Christopher Dummitt and Michael Dawson (eds), Contesting Clio's Craft: New Directions and Debates in Canadian History, Institute of Latin American Studies, London, 2009; Margaret Conrad, 'Public History and its Discontents or History in the Age of Wikipedia', in Journal of the CHA, vol 18, no 1, 2007, p9.

4 Ludmilla Jordanova, History in Practice, 2 Edition, Bloomsbury, London, pp144-145. ${ }^{5}$ High, op cit, p39. See also Andrée Gendreau, 'Museums and Media: A View from Canada', in The Public Historian, vol 31, no 1, 2009, p39.

- Miller and Clarke, op cit, p8.

- Such as: D.M. Norton, Early History of Port Moody, Hancock House, Blaine,

Washington, 1987.

${ }^{\circledR}$ Frederick Turner, Beyond Geography: The Western Spirit Against the Wilderness, Viking Press, New York, 1980, and Roderick Nash, Wilderness and the American Mind, Yale University Press, New Haven, 2001.

- Michael Frisch, 'Working-Class Public History in the Context of Deindustrialization: Dilemmas of Authority and the Possibilities of Dialogue', in Labour/LeTravail, vol 51, 2003, p160.

${ }^{10}$ Jeremy Brecher, 'How I Learned to Quit Worrying and Love Community History: A "Pet Outsider's" Report on the Brass Workers History Project', in Radical History Review, vol 28-30, 1984, p191. For this discussion in Anthropology, see Donald 
Messerschmidt (ed), Anthropologists at Home in North America: Methods and Issues in the Study of One's Own Society, Cambridge University Press, Cambridge, 1981; Kirin Narayan, 'How Native is a "Native" Anthropologist?' in American Anthropologist, vol 95, no 3, 1993, pp671-86; John L. Jackson Jr., Real Black: Adventures in Racial Sincerity, University of Chicago Press, Chicago, 2005, pp153-62.

"Gendreau, op cit, p37.

". Anna Sheftel and Stacey Zembrzychi, 'Introduction', in Anna Sheftel and Stacey Zembrzychi (eds), Oral History Off the Record: Toward an Ethnography of Practice, Palgrave Macmillan, New York, 2013, p14.

${ }^{13}$ On the silencing of alternate memories, see Nicole Neatby and Peter Hodgins, 'Introduction', in Nicole Neatby and Peter Hodgins (eds), Settling and Unsettling Memories: Essays in Canadian Public History, University of Toronto Press, Toronto, 2012, p5.

${ }^{14}$ See, for example, Anne O'Connell, 'An Exploration of Redneck Whiteness in Multicultural Canada', in Social Politics, vol 17, no 4, 2010, pp536-63; Carrol Clarkson, 'Who Are 'We'? Don't Make Me Laugh', in Law Critique, vol 18, 2007, pp361-74; Carol Schick, 'White Resentment in Settler Society', in Race Ethnicity and Education, vol 17, no 1, 2014, pp88-102.

${ }_{15}$ Miller and Clarke, op cit, p6.

${ }^{16}$ Fred Ungless, 'Port Moody Recollections', in Port Moody Station Museum archives, 2011.015.001 (undated).

${ }^{17}$ Miller and Clarke, op cit, p48.

is In contrast, the story of German immigrants who worked at the steel mill was often told. The Germans, it was said, were always impeccably dressed and clean. They showed up to work wearing suits and carrying briefcases, unlike the other workers who showed up already in their grimy coveralls. At the end of the day, whereas most workers went home to shower, the Germans did so at the plant, and returned home their houses always in town - looking spectacular.

19 Port Moody has been affected, for instance, by multiple mud slides, notably one in 1979, and a more recent one in 2009.

${ }^{20}$ Fred Ungless, in his recollections, recounts several stories of Port Moody antics, including the time when a couple of boys stole a goat and drove it into the community hall during a packed all-ages dance, and the time when two men locked the town butcher, Matthew Urquhart, into the freezer overnight and then made off with the till. See Ungless, op cit.

${ }^{2}$ Fink, op cit, p135.

"One man, who worked for one of the sawmills, almost drowned in the inlet after an octopus allegedly grabbed his leg and pulled him under. He only made it to safety after pulling a knife from his boot and cutting away the tentacle. See Miller and Clarke, op cit, p80. There was also a story of a man who donned a wetsuit to help unplug one of the drainage sewers, and who was caught up in the sudden swell and carried clear under the town through the flooded sewer. He survived, and was apparently fine except for the foul mess in the backside of his suit.

${ }_{23}$ Such as several stories of upstanding men who employed minorities in their shops or factories.

${ }^{24}$ Thomas Cauvin, Public History: A Textbook of Practice, Routledge, London, 2016, p62.

${ }_{25}$ Barbara W. Sommer, Practicing Oral History in Historical Organizations, Routledge,

London, 2015, p19.

${ }_{26}$ Jordanova, op cit, p144.

${ }_{27}^{27}$ Fink, op cit, p119.

${ }^{28}$ Lowenthal, op cit, pxi.

${ }_{20}$ Sharon Babaian, 'So Far, So Good: Ethics and the Government Historian', in The Pubic Historian, vol 28, no 1, 2006, p104.

${ }^{30}$ Rebecca Conard, 'Editor's Introduction', in The Public Historian, vol 28, no 1, 2006, p75.

${ }^{31}$ Also among these factors is the higher degree of trust placed on the written over the oral record, a problem that has plagued oral historians more generally. See, for 
example, Alexander Freund, Kristina R. Llewellyn and Nolan Reilly, 'Introduction', in Alexander Freund, Kristina R. Llewellyn and Nolan Reilly (eds), The Canadian Oral History, McGill-Queen's University Press, Montreal and Kingston, 2015, p16, and High, op cit, p34.

${ }_{32}$ Margaret Conrad, Jocelyn Létourneau, and David Northrup, 'Canadians and Their Pasts: An Exploration in Historical Consciousness', in The Public Historian, vol 31, no 1,2009, p31.

${ }^{3}$ George Marcus, Ethnography Through Thick and Thin, Princeton University Press, Princeton, 1998, p105, and Linda Shopes, 'Sharing Authority', in The Oral History Review, vol 30, no 1, 2003, p107.

${ }^{3}$ Marcus, op cit, p6.

${ }^{35}$ Deepa Reddy, 'Caught! The Predicaments of Ethnography in Collaboration', in James Faubion and George Marcus (eds), Fieldwork is Not What it Used to Be: Learning Anthropology's Method in a Time of Transition, Cornell University Press, Ithaca and London, 2009, p96.

${ }^{36}$ On the importance of listening, see Henry Greenspan and Sidney Bolkosky, 'When is an Interview an Interview? Notes From Listening to Holocaust Survivors', in Poetics Today, vol 27, no 2, 2006, pp431-49.

${ }^{37}$ Audra Simpson, 'On Ethnographic Refusal', in Junctures, vol 9, 2007, pp67-80.

${ }^{38}$ Daniel Bradburd, 'Fuzzy Boundaries and Hard Rules: Unfunded Research and the IRB', in American Ethnologist, vol 33, no 4, 2006, p496.

${ }^{3}$ One of these stories was about a local man who lived on a houseboat on the inlet. He had trained a pet seal to follow him up the wharf to the pub, where it would sit with him at the bar. This story was a favourite in the reminiscing meetings, but was clinical when told over the phone, as if it was completely unremarkable.

to Richard Bauman, Story, Performance, and Event, Cambridge University Press, Cambridge, 1986, p4.

"Keith Sawyer, Creating Conversations: Improvisation in Everyday Discourse, Hampton Press, New York, 2001.

"2uke Lassiter, The Chicago Guide to Collaborative Ethnography, University of Chicago Press, Chicago, 2005.

${ }^{43}$ Micaela Di Leonardo, 'Oral History as Ethnographic Encounter', Oral History Review, vol 15, 1987, p4.

" On the potential of misunderstanding, see Jo Blatti, 'Harry Miller's Vision of Arkansas, 1900-1910: A Case Study in Sponsored Projects', in The Public Historian, vol 28, no 1, 2006, p82.

${ }^{45}$ Karl Heider, 'The Rashomon Effect: When Ethnographers Disagree', in American Anthropologist, vol 90, no 1, 1988, p74.

${ }^{46}$ Royal BC Museum, Province of British Columbia Department of Health Services and Hospital Insurance Division of Vital Statistics, Registration of Death, Albert William Kruger.

"An indication of this can be found at the end of Tracks in Time: rather than a standard index of keywords, the author can browse through an 'Index of People', clearly intended for the convenience of old-timers wanting to quickly look up old friends. 